\title{
A methodological approach to define the state of conservation of the stone materials used in the Cairo historical heritage (Egypt)
}

The use of stone materials in cultural heritage and architecture represents a practice that has its roots in ancient times. Stone buildings, depending on the construction materials and their location in the urban context, are particularly vulnerable to weathering phenomena. These can be often accelerated by changes in environmental conditions linked mostly to the anthropic activities. In this way, the present work is addressed on the minero-petrographic and geochemical characterisa-tion of samples taken from the built historical heritage in Cairo (Egypt), related to seven monumental areas. These sites have been chosen based on their historical importance, type of material, state of preservation and position in the Cairo context. The construction materials used and their degradation products were studied comparing the results obtained by means of different analytical techniques such as polarised light optical microscopy (POM), ion chromatography (IC), Fourier transform infrared spectroscopy (FT-IR) and the carbonaceous fraction, detected by using the thermogravimetry (TG). The results achieved demonstrated that black crusts and salt crystallisation represent the most common and dam-aging degradation products affecting all the monumental sites. Moreover, the environmental pollution produced by industrial activities and vehicular traffic has been identified as the main cause of these processes, followed by a marginal contribution of natural sources such as the sea spray. The data collected provide useful information to plan efficient conservation strategies in the future.

Keywords Black crusts · Cultural heritage · Conservation · Degradation · Egypt · Stone

\section{Introduction}

Conservation of built cultural heritage requires a good under-standing of different decay phenomena of stones materials related to textural features and environmental conditions. Stone decay is often ascribable such as an irreversible damage of the cultural heritage, so that the scientific commu-nity focused recently on its conservation all over the world (Fitzner et al. 2000). Both natural and anthropic processes, including respectively weathering and pollution, vandalism and inadequate restoration, can determine an increase in the degradation and alteration phenomena. In this scenario, sedi-mentary stones, mostly carbonate such as limestones, but also dolostones, constitute a very common type of raw materials in built heritage (Delgado Rodrigues and Ferreira Pinto 2019). The preeminent degradation phenomena suffered by limestone can be summarised as soluble salts and black 
crusts. Salt crystallisation is one of the most harmful processes affecting stone building materials, since it produces overpressures on the internal pore-structure of the rock (La Russa et al. 2013a). The presence of salts can be revealed by efflorescence on the surfaces or, once they crystallise, salt crystals within the rock (sub-efflorescence) can increase most decay (Monte 1991; Pires et al. 2010). Black crusts represent a typical patina produced in areas sheltered from direct rainfall or water runoff in urban environments (Araoz 2008). The formation of black crusts occurs mainly on carbonate substrates, whose interactions with an $\mathrm{SO}_{2}$-enriched atmosphere cause the transformation of calcite $\left(\mathrm{CaCO}_{3}\right)$ into gypsum $\left(\mathrm{CaSO}_{4} * 2 \mathrm{H}_{2} \mathrm{O}\right)$. For this reason, the conservation of the building stone heritage needs that a reliable analytical approach is applied, in order to define the relation between the intrinsic properties of the stones and the development of these processes. Ancient Egypt was rebaptised as the "state out of stone", since the stone was the most used raw material during the different periods of Pharaonic Egypt as well as GrecoRoman and Arab times (Klemm and Klemm 2001).

Nowadays, "Cairo is a world heritage city. It contains possibly the finest collection of monuments in the Islamic world especially dated back to the medieval period. Indeed, Cairo's Islamic monuments are part of an uninterrupted tradition that spans over a thousand years of building activity. No other Islamic city can equal Cairo's spectacular heritage. It includes the greatest concentration of Islamic monuments in the world, and its mosques, mausoleums, religious schools, baths and caravanserais, built by prominent patrons between the seventh and nineteenth centuries, are among the finest in existence" (Khallaf 2011).

Unfortunately, the rapid increase in environmental pollution of the last century seriously threatens the archaeological buildings in Cairo and made it necessary to conceive efficient conservation strategies to preserve this precious world heritage. In this regard, different studies underlined the importance to investigate firstly the building raw materials, mostly limestone, because they are susceptible to several decay processes such as black crust formation, salts crystallisation, disintegration, pitting, cracks and erosion (Davidson et al. 2000; Fitzner et al. 2002; Khallaf 2011; Abdelmegeed and Hassan 2019).

The focus of this work is to perform a complete characterisation of stone materials from different building heritage located in Historic Cairo. In particular, a diagnostic approach was applied in order to investigate the degradation phenomena observed in the study area and to define the effective state of conservation of the materials analysed. For this purpose, specimens from different built heritage underwent a complete diagnostic protocol, precisely: petrographic analyses, ion chromatographic analyses, infrared spectroscopic analyses and carbonaceous fraction analysis.

\section{Materials and methods}

Historic Cairo covers an area of $\sim 30 \mathrm{~km}^{2}$, is located in the city centre and holds a large number of Islamic architecture (i.e. mosques, madrasas, hammam and fountains). It dates back to the tenth century in the Fatimid Caliphs age (Anoniou 1999; Williams 2004) and became UNESCO Heritage in 1979.

Eocene limestones extracted from the local quarries of Mokattam and Helwan areas have been exploited for the construction of monuments in Cairo since past until today (Fitzner et al. 2002; Aly et al. 2015, 2018, 2020). Additionally, several of them were reconstructed many times partially or completely over the centuries.

In this study, eighteen stone samples, including their degradation products, were taken from the main facades and walls of seven monumental sites such as Salah El-Din Citadel, the Tower of Bab Al Azab and the Manial Palace, and four representative buildings of the Northern Mamluk cemetery, namely, the Sultan Faraj ibn Barquq Mosque, the Qaitbay Mosque, the Al Silahdar Mosque and the Qansuh Al-Ghuri Mausoleum (Fig. 1).

Table 1 reports the examined samples and a short description about e.g. typology, period of construction, position and height.

Suitable stainless steel tools, such as lancets and small chisels, were employed on a representative portion of the material, in relation to the different macroscopic degradation forms observed, mainly efflorescence, soiling and black crusts.

A complete characterisation of stone materials and degradation products was obtained by the means of the following analytical techniques.

The petrographic analysis was performed in order to define the main textural features of the substrate; the composition of the superficial layers; and the state of conservation of the substrate. For this purpose, polarised optical microscopy (POM), with a Zeiss Axiolab microscope (equipped with a digital camera to capture images), on polished thin sections and stratigraphic sections was carried out.

Ion chromatography (IC) was used to quantify the main anions and cations present on the superficial layers. Each sample underwent the following protocol: $2 \mathrm{mg}$ of powder was placed in a test tube and treated with $10 \mathrm{~mL}$ of MilliQ water. The solutions were sonicated for $1 \mathrm{~h}$, then centrifuged for 30 min and analysed by mean an HPLC (DIONEX DX 120). Cationic $\left(\mathrm{Na}^{+}, \mathrm{K}^{+}, \mathrm{Ca}^{2+}, \mathrm{Mg}^{2+}\right.$ and $\left.\mathrm{NH}_{4}\right)$ and anionic $\left(\mathrm{NO}^{3-}, \mathrm{SO}_{4}{ }^{2}, \mathrm{Cl}^{-}\right)$species were determined for each sample.

Fourier transform infrared spectroscopy (FT-IR) measurements were carried out to determine the mineralogical phases constituting the examined superficial layers. Analyses were performed through a Perkin Elmer Spectrum 100 spectrophotometer equipped with an ATR (attenuated total reflectance) accessory.

As regards the carbonaceous fraction, $\mathrm{OC}$ (organic carbon), EC (elemental carbon) and CC (carbonatic carbon) have been quantified. The TGA (thermo-gravimetric analysis) 


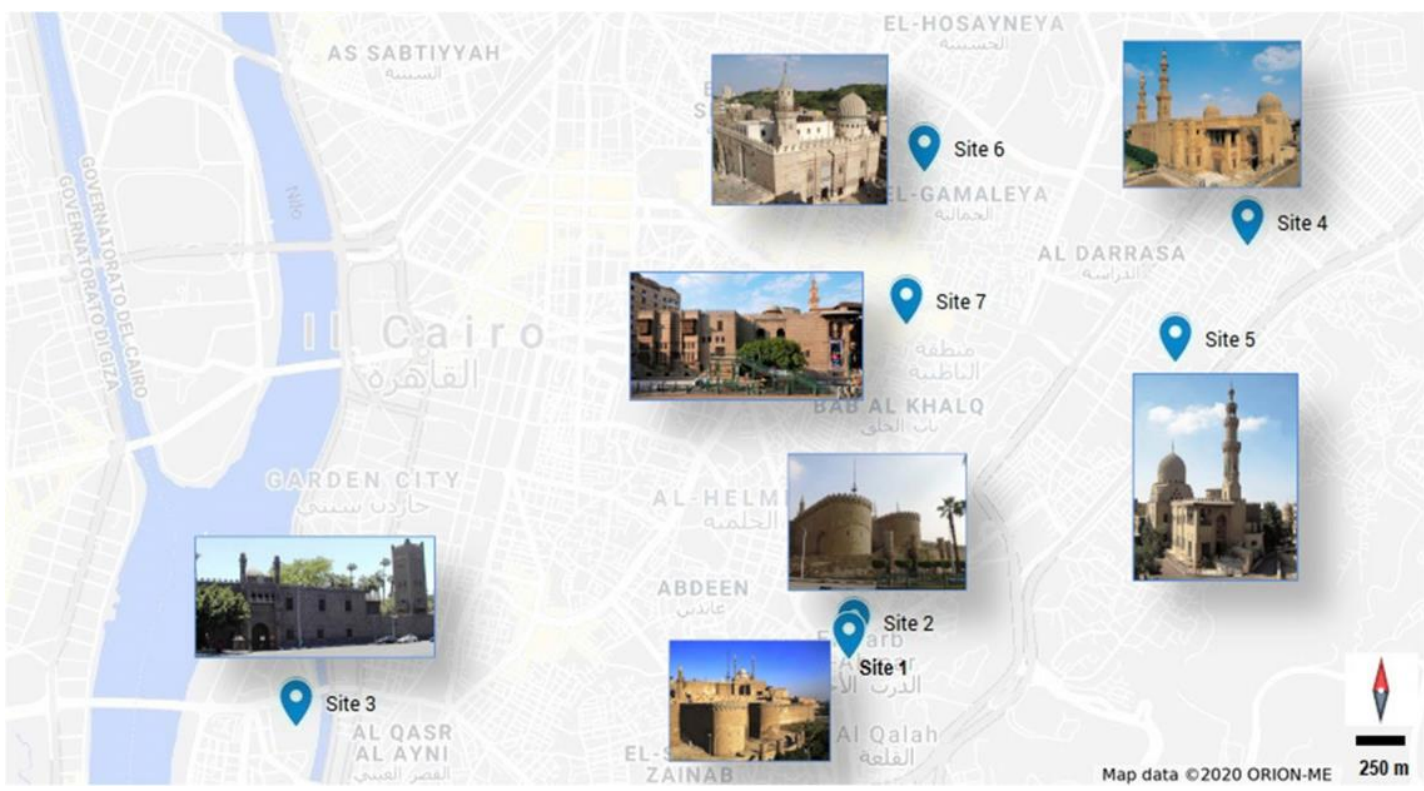

Fig. 1 Road map of Historic Cairo (source: Google Maps modified). The blue icons and the photographs associated indicate the location of the sampled monuments. Site 1: Outer walls of Salah El-Din Citadel; site 2: tower of Bab Al Azab; site 3: Manial Palace, Northern Mamluk cemetery area; site 4: Sultan Faraj ibn Barquq Mosque (image credits: Discover
Islamic Art - MWNF); site 5: Qaitbay Mosque (image credits: Discover Islamic Art - MWNF); site 6: Al Silahdar Mosque (image credits: Archive ARCE- American Research Centre in Egypt); site 7: Qansuh Al-Ghuri Mausoleum (image credits: Archnet.org)
Table 1 List and information about the samples collected in Historic Cairo, constituted by degradation layer (DL) and stone substrate ( $L S$, limestone substrate; $Q S$, quartz arenite substrate). The historical information about the building epoch of the monuments was drawn from William (2004). The coordinates in WGS84 system were acquired from Google Earth

\begin{tabular}{|c|c|c|c|c|c|}
\hline Sample ID & Location & Description & Position & Height of sampling $(\mathrm{cm})$ & WGS 84 coordinates \\
\hline \multicolumn{6}{|c|}{ Site 1-Salah El-Din Citadel (1176-1183 AD) } \\
\hline 4 & North-western outer wall & $\mathrm{DL}+\mathrm{LS}$ & Vertical Surface & 250 & \multirow[t]{2}{*}{$30.03043,31.25791$} \\
\hline 6 & North-western outer wall & $\mathrm{DL}+\mathrm{LS}$ & Vertical Surface & 35 & \\
\hline \multicolumn{6}{|c|}{ Site 2-Tower of Bab Al Azab (1754 AD) } \\
\hline 5 & Western wall & $\mathrm{DL}+\mathrm{LS}$ & Vertical Surface & 25 & \multirow[t]{2}{*}{$30.03106,31.25816$} \\
\hline 7 & Western wall & $\mathrm{DL}+\mathrm{LS}$ & Vertical Surface & 155 & \\
\hline \multicolumn{6}{|c|}{ Site 3-Manial Palace (1899-1929 AD) } \\
\hline 8 & Northern wall & $\mathrm{DL}+\mathrm{QS}$ & Vertical Surface & 45 & \multirow[t]{3}{*}{$30.02744,31.22897$} \\
\hline 9 & Northern wall & $\mathrm{DL}+\mathrm{LS}$ & Vertical Surface & 20 & \\
\hline 10 & Northern wall & $\mathrm{DL}+\mathrm{LS}$ & Vertical Surface & 30 & \\
\hline \multicolumn{6}{|c|}{ Northern Mamluk cemetery (13th-15th centuries AD) } \\
\hline \multicolumn{6}{|c|}{ Site 4-Sultan Faraj ibn Barquq Mosque (1400-1411) } \\
\hline 17 & Main facade & $\mathrm{DL}+\mathrm{LS}$ & Vertical Surface & 20 & \multirow[t]{2}{*}{$30.04919,31.27876$} \\
\hline 18 & Main facade & $\mathrm{DL}+\mathrm{LS}$ & Vertical Surface & 200 & \\
\hline \multicolumn{6}{|c|}{ Site 5-Qaitbay Mosque (1472-1474) } \\
\hline A & Main facade & $\mathrm{DL}+\mathrm{LS}$ & Vertical Surface & 90 & \multirow[t]{3}{*}{$30.04388,31.27499$} \\
\hline $\mathrm{C}$ & Main facade & $\mathrm{DL}+\mathrm{LS}$ & Vertical Surface & 200 & \\
\hline $\mathrm{D}$ & Main facade & $\mathrm{DL}+\mathrm{LS}$ & Vertical Surface & 50 & \\
\hline \multicolumn{6}{|c|}{ Site 6-Al Silahdar Mosque (1344-1345) } \\
\hline $\mathrm{F}$ & Main facade & $\mathrm{DL}+\mathrm{LS}$ & Vertical Surface & 100 & \multirow[t]{2}{*}{$30.05249,31.26187$} \\
\hline $\mathrm{G}$ & Main facade & $\mathrm{DL}+\mathrm{LS}$ & Vertical Surface & 50 & \\
\hline \multicolumn{6}{|c|}{ Site 7-Qansuh Al-Ghuri Mausoleum (1503-1505) } \\
\hline I & Main Facade & $\mathrm{DL}+\mathrm{LS}$ & Vertical Surface & 90 & $30.04565,31.26088$ \\
\hline
\end{tabular}


instrument was used to quantify the carbon fraction. The analyses were carried out with a Mettler Toledo TGA/DSC 3 instrument that allows simultaneous TG and DSC analyses, in a range between 30 and $800^{\circ} \mathrm{C}$, increasing the temperature with a speed of $20^{\circ} \mathrm{C} / \mathrm{min}$ in two different atmospheres, inert and oxidising. Calculations were carried out for the determination of the carbonaceous fractions present in the crusts, through the study of standards following the procedure described in La Russa et al. (2017). In particular, the analytical protocol applied is a thermal method based of the different thermal behaviours of carbon fractions: while OC decomposes at a lower temperature (about $340{ }^{\circ} \mathrm{C}$, atmosphere inert), EC (range at 400 and $600{ }^{\circ} \mathrm{C}$, atmosphere oxidising), Ox (range at 400 and $600{ }^{\circ} \mathrm{C}$, atmospheres inert) and $\mathrm{CC}$ (range at 600 and $800{ }^{\circ} \mathrm{C}$, atmospheres inert and oxidising) are stable up to high temperature. The analysed samples were previously powdered through the use of an agate mortar, carefully separating the black crust and the substrate through the use of a scalpel.

\section{Results and discussions}

\section{Petrographic analysis}

Petrographic observations on thin sections revealed some remarkable variations regard to the adherence, thickness and morphology of the superficial layers on the substrate of the specimens and then on their state of conservation.

The main minero-petrographic features and the most representative microphotographs are reported respectively in Table 2 and Fig. 2.

Samples 4 and 6 were taken at different heights along the western external walls of the Salah El-Din Citadel (site 1) and show different features both regard to the substrate and to the crust.

On the basis of textural features, sample 4 can be classified such as biomicrite (Folk 1959) or mudstone (Dunham 1962) (Fig. 2a). The superficial layer, constituted by gypsum, shows a uniform thickness (about $50 \mu \mathrm{m}$ ), a good adherence, an irregular external morphology, brown colour and carbonaceous particles (Fig. 2a). These latter ones show a sub-spherical shape and averagely $30 \mu \mathrm{m}$ in size. Regarding the state of conservation, the analysed sample seems to be poorly degraded.

Sample 6 is an intrasparite (Folk 1959) or a packstone (Dunham 1962), where some quartz crystals and bioclasts are present. The superficial layer consists mainly of gypsum, is greyish in colour, has a homogeneous thickness (about $100 \mu \mathrm{m})$, has irregular external morphology and contains sub-spherical carbonaceous particles. The degradation degree is suggested by microfractures along the contact between substrate and superficial layer, visible only in some portions.

Samples 5 and 7 come from the tower of $\mathrm{Bab} \mathrm{Al}$ Azab (site 2).

Table 2 The main minero-petrographic features observed by OM about the substrate (according to Folk 1959 and Dunham 1962 classifications) and the superficial alteration layer. The state of conservation refers to the substrate as reported in the text and it is distinguished in poor, fair and good

\begin{tabular}{|c|c|c|c|c|c|c|}
\hline \multirow[t]{2}{*}{ Sample ID } & & \multirow[t]{2}{*}{ Substrate } & \multicolumn{3}{|l|}{ Alteration layer } & \multirow{2}{*}{$\begin{array}{l}\text { State of } \\
\text { conservation }\end{array}$} \\
\hline & & & Total thickness $(\mu \mathrm{m})$ & Morphology & Mineral composition & \\
\hline \multirow[t]{2}{*}{ Site 1} & 4 & Biomicrite mudstone & 50 & Irregular A & Gy; CP & Good \\
\hline & 6 & Intrasparite packstone & 100 & Irregular N.A. & Gy; CP & Fair \\
\hline \multirow[t]{2}{*}{ Site 2} & 5 & Pelmicrite mudstone & 200 & Irregular N.A. & Gy; Qtz; Oxd; CP & Good \\
\hline & 7 & Biosparite packstone & $\operatorname{Max} 100 *$ & Regular A & Gy; Qtz; Oxd; CP & Fair \\
\hline \multirow[t]{3}{*}{ Site 3} & 8 & Quartz arenite & $\operatorname{Max} 100 *$ & Irregular A & Gy & Good \\
\hline & 9 & Biosparite wackestone & $\operatorname{Max} 100 *$ & Jagged A & Gy; Qtz; Oxd; CP & Fair \\
\hline & 10 & Biomicrite packstone & $100-500$ & Jagged N.A. & Gy; CP & Fair \\
\hline \multirow[t]{2}{*}{ Site 4} & 17 & Biosparite wackestone & $100-50$ & Irregular A & Gy; CP & Good \\
\hline & 18 & Biomicrite wackestone & $200-400$ & Dendritic N.A. & Gy; Qtz; Oxd; CP & Good \\
\hline \multirow[t]{3}{*}{ Site 5} & A & Intramicrite wackestone & 200 & Regular A & Gy; CP & Good \\
\hline & $\mathrm{C}$ & Biomicrite mudstone & $100 *$ & Irregular A & Gy; Oxd; CP & Good \\
\hline & $\mathrm{D}$ & Biomicrite wackestone & $50-100 *$ & Irregular N.A. & Gy; Oxd; CP & Good \\
\hline \multirow[t]{2}{*}{ Site 6} & $\mathrm{~F}$ & Intramicrite mudstone & 100 & Dendritic A & Gy; CP & Poor \\
\hline & G & Biomicrite wackestone & $\operatorname{Max} 100 *$ & Irregular N.A. & Gy; Qtz; Oxd; CP & Fair \\
\hline Site 7 & I & Biomicrite mudstone & $100-200$ & Regular A & Gy; Qtz; CP & Fair \\
\hline
\end{tabular}

*Discontinuous and variable thickness

$G y$, gypsum; $Q t z$, quartz; $O x d$, oxides; $C P$, carbonaceous particles; $A$, adherent to the substrate; $N . A$., not well adherent to the substrate 
Fig. 2 Microphotographs in OM showing the main textural features of the limestones and the superficial layer associated. The red lines highlight the contact between the two components. The allochems present are indicated respectively with "All" (fossils and bioclasts), "Pl" (plagioclase), "Qtz" (quartz). A sample and relative image were selected for each study site. a Sample 4, site 1 (crossed polarised light view, CPL). b Sample 5, site 2 (plane polarised light view, PPL). c Sample 10, site 3 (CPL). d Sample 18, site 4 (CPL). e sample D, site 5 (PPL). f Sample G, site 6 (CPL). g Sample I, site 7 (CPL)
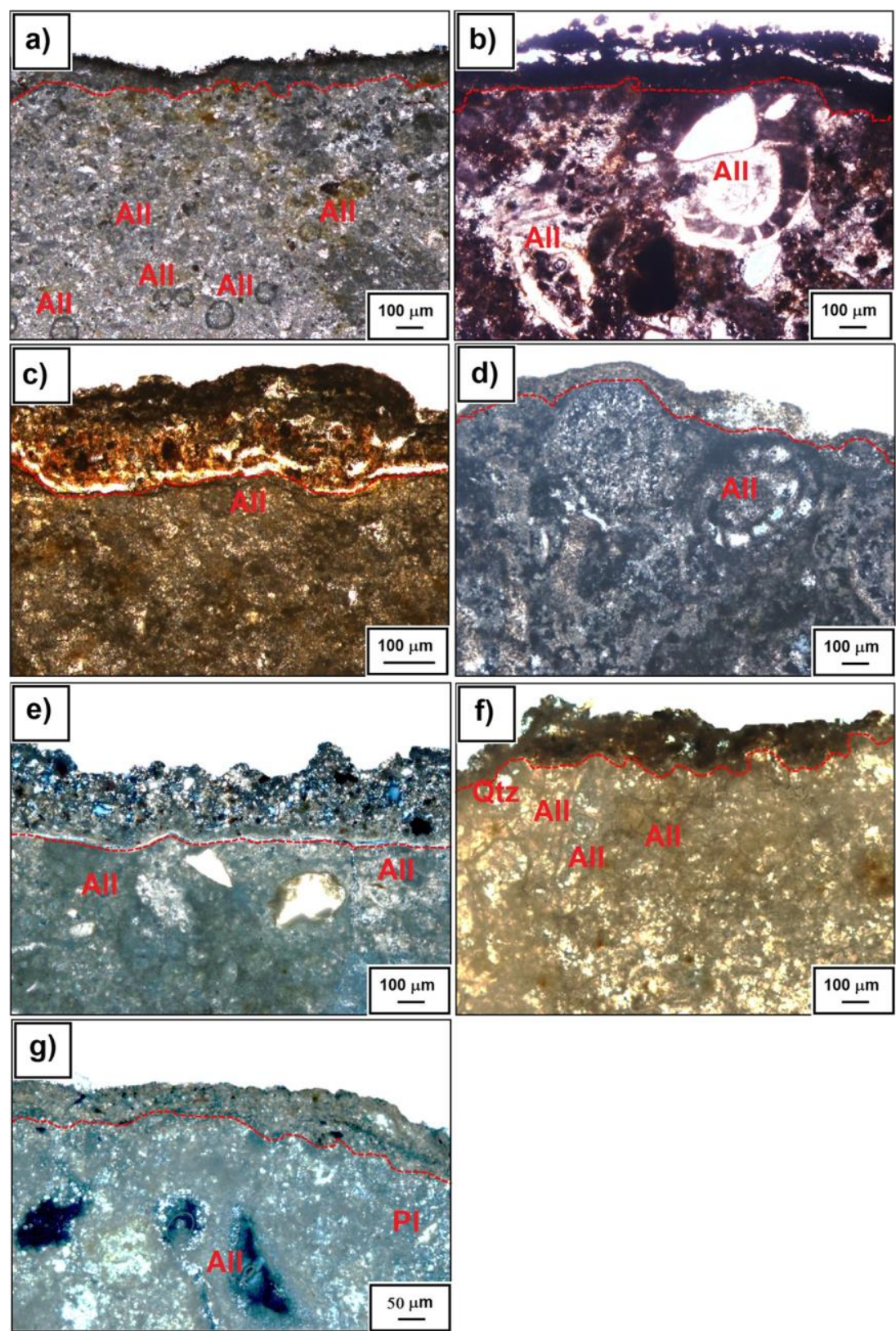

Sample 5 is a pelmicrite (Folk 1959) or a mudstone (Dunham 1962) with common quartz crystals. The superficial layer shows a variable thickness of around $200 \mu \mathrm{m}$, divided into two levels, both of about $100 \mu \mathrm{m}$ (Fig. 2b). The outermost one is darker in colour and shows an irregular morphology and a compact aspect. The innermost one is reddish in colour, with different microfractures (Fig. 2b). The substrate is in a good state of conservation.

Sample 7 is a biosparite according to Folk (1959) or a packstone (Dunham 1962). The allochem component is mainly formed by quartz, opaque minerals, probably iron oxides and also bioclasts such as gastropods. The superficial layer is discontinuous; the thickness is variable, reaching $100 \mu \mathrm{m}$ in some portions. The layer shows good adherence to the substrate, a rather regular external morphology and a colour ranging from brownish to black. It contains microcrystalline gypsum, quartz, iron oxides and sub-spherical carbonaceous particles $10-50 \mu \mathrm{m}$ in size. The conservation degree of the substrate is fair with occasional phenomena of secondary dissolution of some bioclasts.

Samples 8, 9 and 10 were taken from the Manial Palace (site 3).

Specimen 8 is a quartz arenite; on its surface, it is clear the presence of a discontinuous deposit, brown in colour, with a variable thickness, the maximum being of $100 \mu \mathrm{m}$. The substrate shows a good state of conservation. 
Sample 9 is a biosparite (Folk 1959) or a wackestone (Dunham 1962). The allochem fraction consists mainly of quartz, iron oxides and also bioclasts such as Macroforaminifera and gastropods. The superficial layer is discontinuous, well adhered to the substrate and brownish in colour with a variable thickness, reaching $100 \mu \mathrm{m}$ only in some points. The external morphology is irregular and the profile is jagged. Microcrystalline gypsum, quartz, iron oxides and sub-spherical carbonaceous particles were identified in the layer.

Sample 10 is a biomicrite (Folk 1959), with abundant bioclasts (> 10\%) mainly represented by foraminifera; additionally, it is classifiable as packstone according to Dunham (1962). The alteration layer is not well adhered to the substrate, has a thickness ranging between 100 and $500 \mu \mathrm{m}$, is dark in colour and has jagged outer edge (Fig. 2c). Inside it, there are spherical carbonaceous particles and rare gypsum crystals.

Samples 17 and 18 are related to the Sultan Faraj ibn Barquq Mosque (site 4).

Sample 17 is a biosparite (Folk 1959) or wackestone (Dunham 1962). The alteration layer is present only in some areas with a thickness ranging from 10 to $50 \mu \mathrm{m}$; it is constituted by gypsum and common sub-spherical carbonaceous particles of about $10-20 \mu \mathrm{m}$ in diameter.

Sample 18 is a biomicrite (Folk 1959) or a wackestone (Dunham 1962). The allochems are constituted by quartz, opaque minerals such as iron oxides, calcareous rock fragments and fossiliferous fragments (Fig. 2d). The superficial layer shows a dendritic morphology, colour varying from greyish to brownish; it is separated by a fracture from the substrate (Fig. 2d). The thickness ranges from 200 to $400 \mu \mathrm{m}$. The layer includes microcrystalline gypsum, quartz, iron oxides and sub-spherical carbonaceous particles 30$50 \mu \mathrm{m}$ in size.

Both substrates show a good state of conservation.

Samples A, C and D come from the Qaitbay Mosque (site 5).

Sample A is an intramicrite (Folk 1959) or a wackestone (Dunham 1962). The superficial layer has a thickness of about $200 \mu \mathrm{m}$, is firmly attached to the substrate and shows a rather regular outer profile. Three levels are distinguishable: the outer layer has a dark brown colour and a thin thickness that does not exceed $50 \mu \mathrm{m}$; the intermediate layer has a greyish colour, with a variable thickness of around $100 \mu \mathrm{m}$ and is particularly rich in carbonaceous particles; the innermost layer, at the interface with the substrate, is brownish and shows a variable thickness, from 20 to $50 \mu \mathrm{m}$.

Sample C is a biomicrite (Folk 1959) or a mudstone according to Dunham (1962). The allochems consist of iron oxides and fossils, in particular macroforaminifers such as nummulites. The superficial layer is rather discontinuous, dark brown in colour, approximately $100 \mu \mathrm{m}$ thick and well adherent to the substrate. Rare gypsum crystals iron oxides and carbonaceous particles were identified.
Sample D is a biomicrite (Folk 1959) with particularly abundant foraminifera and a wackestone according to Dunham's classification system (Dunham 1962). The superficial layer is brownish grey, quite thin (about $50 \mu \mathrm{m}$ and not more than $100 \mu \mathrm{m}$ ) and not regularly present on the substrate (Fig. 2e). Microcrystalline gypsum is the main component followed by few carbonaceous particles and iron oxides. Overall, the degree of conservation of the substrate in all the samples is rather good.

Samples F and G come from the Al Silahdar Mosque (site 6).

Sample F is an intramicrite (Folk 1959) or mudstone (Dunham 1962), with quartz and plagioclase crystals inside $(<10 \%)$. The superficial layer presents a variable thickness of about $100 \mu \mathrm{m}$, a good adherence to the substrate and an irregular dendritic morphology. Additionally, it can be divided into two different levels: the outer one shows a dark brown colour, a thickness of approximately $70 \mu \mathrm{m}$ and a good concentration of sub-spherical carbonaceous particles, $10-20 \mu \mathrm{m}$ in size; the inner layer appears yellowish and thinner with a thickness of $\max 30 \mu \mathrm{m}$. The contact layer/substrate is rather continuous and sharp. The state of conservation is scarce because of different microfracture systems crossing the substrate.

Sample G is a biomicrite (Folk 1959) or a wackestone (Dunham 1962). The allochemical components are constituted by quartz, plagioclase, iron oxides and bioclasts.

The superficial layer is present only partially on the substrate. The main composition is represented by microcrystalline gypsum, quartz, black and brown iron oxides, and sub-spherical carbonaceous particles $10-30 \mu \mathrm{m}$ in size. The layer shows a brownish colour; the average thickness is about $100 \mu \mathrm{m}$.

Its adherence to the substrate is good in some points but discontinuous and irregular in others, where the layer pierces inside for a maximum of $50 \mu \mathrm{m}$ by means of microfractures (Fig. 2f). For this reason, the state of conservation of the substrate is not considered good.

Sample I was taken from the Qansuh Al-Ghuri Mausoleum (site 7). It is classified such as a biomicrite (Folk 1959) or a mudstone (Dunham 1962). The bioclasts are mainly foraminifera; the superficial layer is thin, with a variable thickness between 100 and $200 \mu \mathrm{m}$; it shows a blackish colour and a good adherence on the substrate (Fig. 2g). The main constituent is gypsum but there is also a low amount of quartz crystals. The state of conservation is fair since the layer can penetrate for about $50 \mu \mathrm{m}$ in the substrate.

Overall, most substrates are constituted by limestone except for a quartz arenite (sample 8). The classification criteria of Folk (1959) and Dunham (1962) suggest a certain compositional and textural heterogeneity coherently with the rocks extracted in the local quarries. Mostly biomicrites were identified, followed by intramicrites and biosparites (Folk 1959), mudstone, wackestone and finally packstone (Dunham 1962). The substrates inside, show a fair state of conservation with some cases 
of internal fracturing or secondary porosity, for example, relative to the dissolution of the bioclasts. Conversely, all of them are affected by a superficial layer of alteration, generally discontinuous in samples 7, 8, 9, D and G, rather continuous in the others with an average thickness of $100 \mu \mathrm{m}$ and reaching in some cases 400-500 $\mu \mathrm{m}$ (samples 10-18). The contact layer/ substrate is commonly linear and sharp, with a rare penetration of the layer inside by the means of some microfractures up to $50 \mu \mathrm{m}$ (samples F, G, I).

\section{Ion chromatography}

Several ionic species can be detected in building stones (Arnold 1983; Goudie and Viles 1995), in particular sulphates, chlorides and nitrates. In Fig. 3a, it has been reported the concentrations expressed in ppm of several cations and anions measured in black crusts samples. It is clear that calcium and sulphate ions are the most abundant species because the black crust is mainly made of gypsum, which has a solubility of about $2.5 \mathrm{~g} / \mathrm{L}$, and the preparation procedure of the sample for IC analysis leads to the complete dissolution of the gypsum. This statement is corroborated by the ionic trend of calcium and sulphate ions shown in Fig. 4. Those trends, which report the ppm concentrations in each sample, show a superimposition of the curves revealing a strong correlation between calcium and sulphate. In Fig. $3 b$, it has been reported the concentrations of analysed ions, excluding calcium and sulphate. It shows that sodium and chloride ions have the highest concentrations, suggesting the presence of sodium chloride, especially in samples 17,10 and 9.

Sulphates are common degradation products coming from different sources and present mostly on masonries of both ancient and modern buildings and also on frescoes and wall paintings. They crystallise in three different forms such as gypsum $\left(\mathrm{CaSO}_{4} \cdot 2 \mathrm{H}_{2} \mathrm{O}\right)$, mirabilite $\left(\mathrm{Na}_{2} \mathrm{SO}_{4} \cdot 10 \mathrm{H}_{2} \mathrm{O}\right)$ and epsomite $\left(\mathrm{MgSO}_{4} \cdot 7 \mathrm{H}_{2} \mathrm{O}\right)$ (Arnold 1983; Borrelli 1999).
Atmospheric pollution provides the most relevant contribution to their crystallisation processes thanks to the high concentration of sulphur dioxide available. In fact, it combined with the air humidity, reacts with the calcium carbonate present in the masonry constituents (i.e. mortars, stones, concrete, etc.) and produces calcium sulphates (Borrelli 1999). Additionally, some types of cement such as Portland originally contain already low percentages of calcium sulphate $(\sim 4 \%)$.

Otherwise, the salts can be deposited directly from particulate matter on the surfaces.

Moreover, sulphates can precipitate from water rising for capillary action from the subsoil. They can derive from ammonium sulphate used in agriculture.

Lastly, sulphate sources can be considered also, namely sea spray and the biological activity of some micro-organisms. These can to metabolise compounds in calcareous materials, containing reduced forms of sulphur and oxidise them to sulphates (Caneva et al. 1991).

Chloride-based salts are the most common ones and can be produced from various sources such as sea aerosol, groundwater loaded with salts, impurities in mortars, concretes, natural stones and other building materials, and emissions into the atmosphere of hydrochloric acid coming from different industrial activities. Some stones naturally contain chlorides, as it is the case for Egyptian limestone (Gauri 1981; Aly et al. 2015). The high solubility makes chlorides highly damaging because they can migrate deeply and crystallise into stone materials producing intense sub-efflorescence and consequently micro-cracks and the destruction of the pore structure (Borrelli 1999; Fitzner et al. 2002).

In particular, halite $(\mathrm{NaCl})$ is the predominant salt species in Egyptian soil and one of the most damaging (Fitzner et al. 2002; Khallaf 2011; Abdelmegeed and Hassan 2019). Its abundance in Historic Cairo buildings was due to the combination of surrounding deterioration factors, especially groundwater and sewage, and lack of infrastructure system (Abdelmegeed and Hassan 2019).

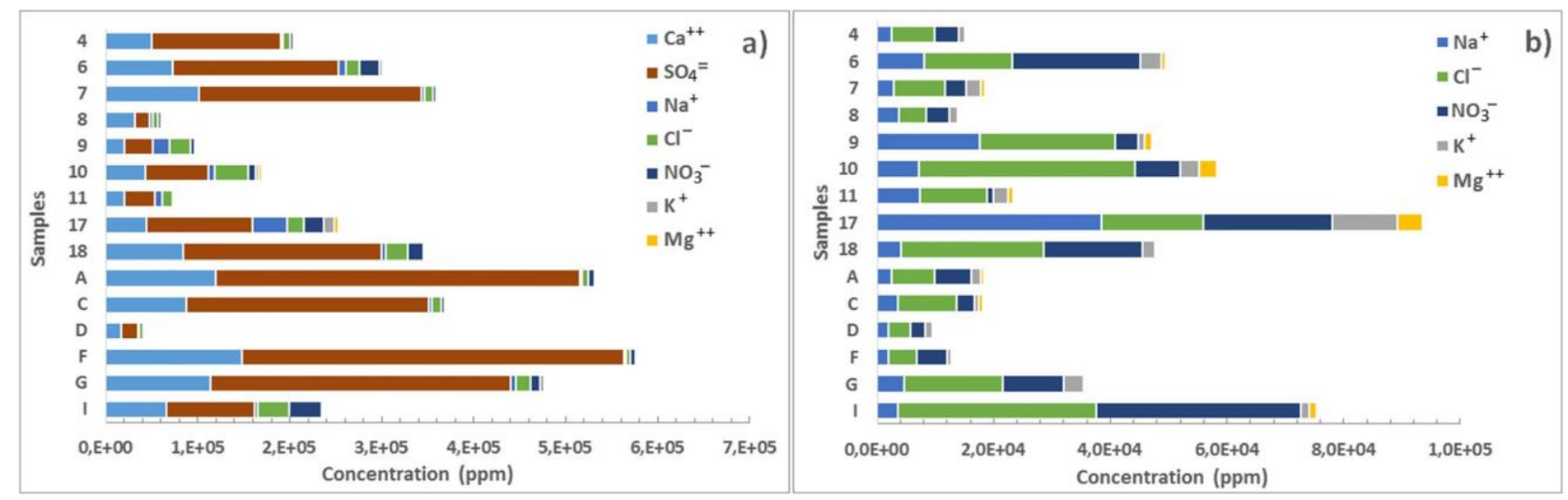

Fig. 3 Ionic concentrations measured in samples: chart a contains all considered ions, while in chart b, calcium and sulphate ions are excluded 
Fig. 4 Concentrations trends in samples of sulphate and calcium ions

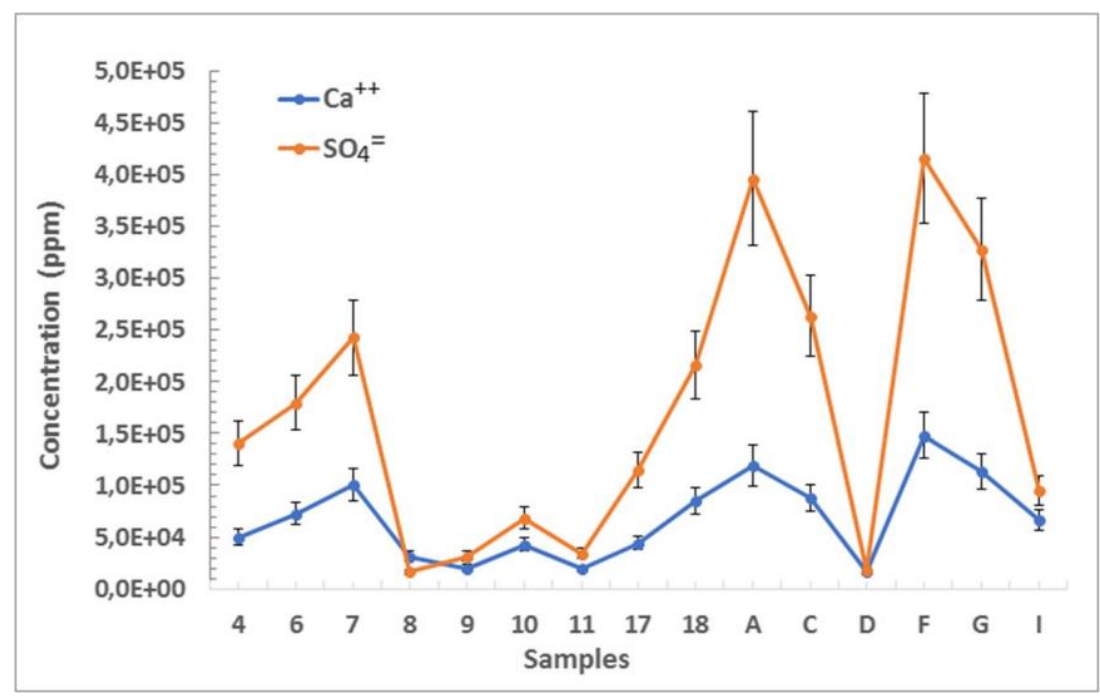

Nitrates were also found in all samples, with peaks in $6,17,18$ and I. Their production is closely relative to the nitrogen pollutants present in the atmosphere and linked for example to the domestic and industrial fuel burnings (Khallaf 2011) or to the photochemical smog, commonly diffused in areas with high rates of pollution combined with long periods of solar radiation.

The organic decomposition of the nitrogen products present in the soil or in the walls can induce the production of nitrites. Their main source is attributable to the infiltration of sewage and this can be the case as most of the foundations and walls of the Islamic monuments in Historic Cairo have been affected by the flooding of the sewage water (El-Metwally and Ramadan 2004). Nitrates may exist also in ground soil as a result of decaying organic material. In this regard, Fitzner et al. (2002) underline how the water table (groundwater, subsoil water) has significantly risen during the last decades in Historic Cairo and in extreme cases has reached the ground floor of monuments. This situation accentuated the insufficiency or even the absence of sewage systems, causing an increase in water pollution.

Nevertheless, the tendency for nitrites $\left(\mathrm{NO}^{2-}\right)$ to oxidise to nitrates $\left(\mathrm{NO}^{3-}\right)$ makes it difficult to find them in masonry (Borrelli 1999).

\section{FT-IR analysis}

Table 3 displays FT-IR data obtained on the analysed samples and Fig. 5 shows some representative spectra. The main components detected in all the crusts are gypsum, oxalate and calcite, typical black crust compounds. Precisely, spectra show the characteristic absorption peaks of gypsum centred at $672,1109,1684,3397$ and $3533 \mathrm{~cm}^{-1}$, as well as the stretching and bending vibrations of the calcium carbonate, with peaks at 1405,872 and $712 \mathrm{~cm}^{-1}$ can be certainly ascribable to the underlying substrate (Vahur et al. 2016).

Table 3 reports the qualitative estimates expressed in percentages based on the intensity of the peaks. In this regard, gypsum is the most abundant mineralogical species; its relative abundance varies from $>50$ (samples $4,10,17,18, \mathrm{~A}, \mathrm{D}$, F, G and I) to 20-50\% (samples 5, 7, 8 and C). Also, calcite varies from 10 to $5 \%$ (samples $7,8,9,10,18$, D and I) to 1$5 \%(4,6,17, \mathrm{~A}, \mathrm{C}, \mathrm{F}$ and $\mathrm{G})$ according to the qualitative valuation. Finally, oxalates (with peaks at 1618, 1321 and $780 \mathrm{~cm}^{-1}$ ) and silicates (peaks centred between 1000 and $1030 \mathrm{~cm}^{-1}$ ) are rather scarce not exceeding $5 \%$.

Table 3 Mineralogical composition of the crusts collected in Cairo monuments by FT-IR (gypsum; calcite; oxalates; and silicate)

\begin{tabular}{llllll}
\hline Sample ID & & Gypsum & Calcite & Oxalates & Silicates \\
& & & & + & + \\
Site 1 & 4 & +++++ & + & + & + \\
& 6 & ++++ & + & + & + \\
Site 2 & 5 & ++++ & + & + & + \\
& 7 & ++++ & ++ & + & + \\
Site 3 & 8 & ++++ & ++ & + & + \\
& 9 & ++++ & ++ & + & + \\
& 10 & +++++ & ++ & + & + \\
Site 4 & 17 & +++++ & + & + & + \\
& 18 & +++++ & ++ & + & + \\
Site 5 & A & +++++ & + & + & + \\
& C & ++++ & + & + & + \\
& D & +++++ & ++ & + & + \\
Site 6 & F & +++++ & + & + & + \\
& G & +++++ & + & + & + \\
Site 7 & I & +++++ & ++ & + & +
\end{tabular}

+++++ > $50 \% ;++++: 20-50 \% ;+++: 10-20 \% ;++: 10-5 \% ;+: 1-5 \%$ 

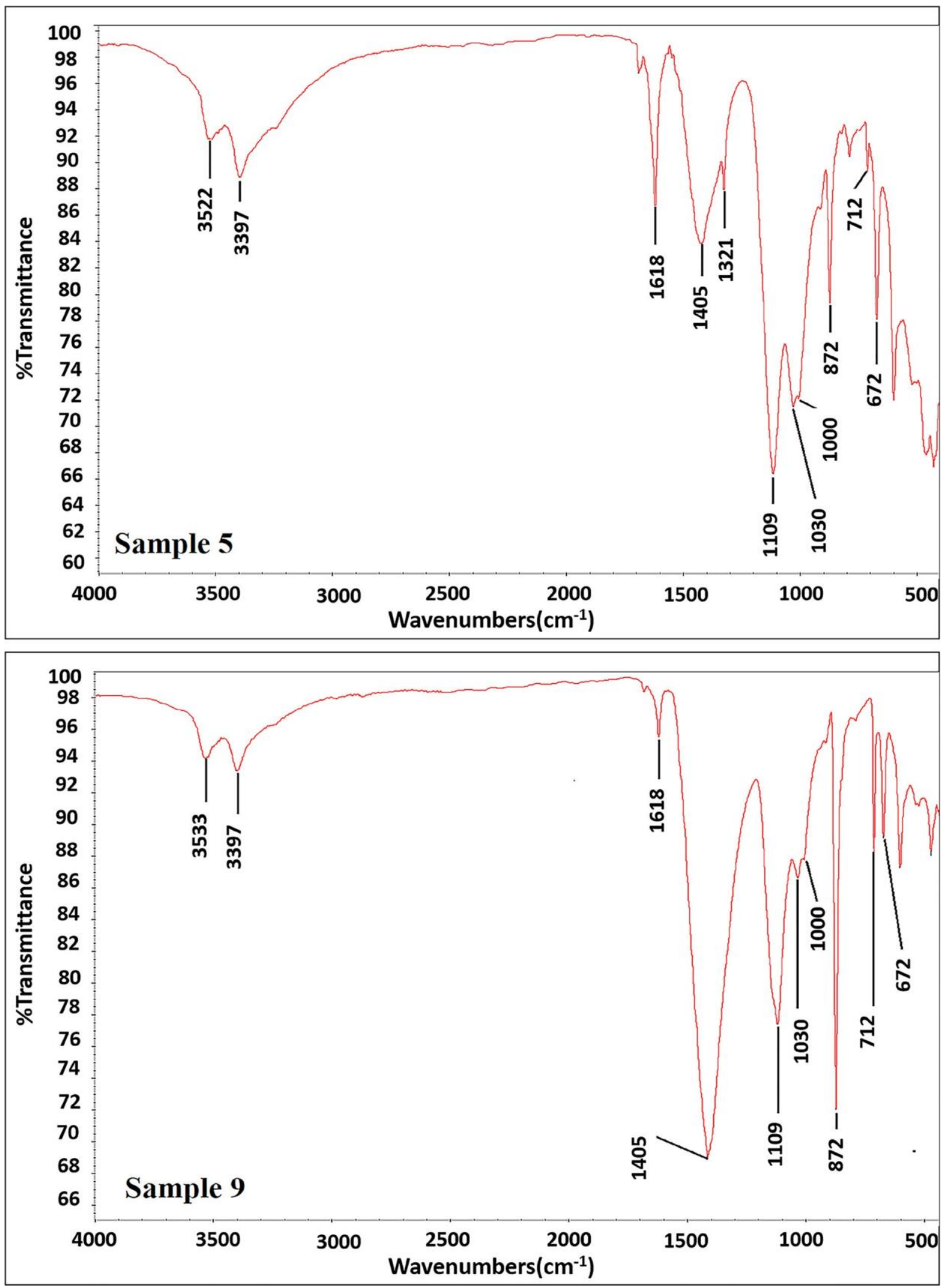

Fig. 5 FT-IR spectra of representative crust of samples 5 and 9 
Table 4 TC (total carbon); OC (organic carbon); EC (elemental carbon); OX (oxalate), CC (carbonate carbon); and Gy (gypsum) concentrations (wt.\%) achieved in the degradation layers analysed

\begin{tabular}{|c|c|c|c|c|c|c|c|c|}
\hline Site & Sample ID & Height of sampling & $\mathrm{OC}$ & $\mathrm{EC}$ & OX & $\mathrm{CC}$ & $\mathrm{TC}$ & Gy \\
\hline \multirow[t]{2}{*}{ Site 1} & 4 & $2.50 \mathrm{~m}$ & 1.33 & 1.50 & 0.11 & 3.66 & 6.60 & 22.97 \\
\hline & 6 & $35 \mathrm{~cm}$ & 1.20 & 2.73 & 0.13 & 3.12 & 7.18 & 26.44 \\
\hline \multirow[t]{2}{*}{ Site 2} & 5 & $25 \mathrm{~cm}$ & 1.19 & 2.89 & 0.34 & 3.03 & 7.45 & 6.01 \\
\hline & 7 & $1.55 \mathrm{~m}$ & 1.20 & 1.33 & 0.34 & 3.03 & 5.90 & 36.00 \\
\hline \multirow[t]{3}{*}{ Site 3} & 8 & $45 \mathrm{~cm}$ & 1.58 & 5.44 & 0.33 & 6.01 & 13.36 & 1.53 \\
\hline & 9 & $20 \mathrm{~cm}$ & 1.88 & 5.95 & 0.14 & 7.22 & 15.19 & 1.32 \\
\hline & 10 & $30 \mathrm{~cm}$ & 1.85 & 1.95 & 0.11 & 7.23 & 11.14 & 7.01 \\
\hline \multirow[t]{2}{*}{ Site 4} & 17 & $20 \mathrm{~cm}$ & 0.56 & 2.85 & 0.26 & 5.11 & 8.78 & 15.57 \\
\hline & 18 & $2 \mathrm{~m}$ & 0.86 & 1.15 & 0.12 & 3.15 & 5.28 & 30.99 \\
\hline \multirow[t]{3}{*}{ Site 5} & A & $90 \mathrm{~cm}$ & 1.11 & 1.56 & 0.23 & 5.22 & 8.12 & 50.46 \\
\hline & $\mathrm{C}$ & $2 \mathrm{~m}$ & 0.36 & 0.99 & 0.22 & 3.99 & 5.56 & 36.57 \\
\hline & $\mathrm{D}$ & $50 \mathrm{~cm}$ & 1.15 & 2.65 & 0.12 & 2.45 & 6.37 & 1.50 \\
\hline \multirow[t]{2}{*}{ Site 6} & $\mathrm{~F}$ & $1 \mathrm{~m}$ & 0.99 & 1.88 & 0.12 & 5.11 & 8.10 & 55.60 \\
\hline & $\mathrm{G}$ & $50 \mathrm{~cm}$ & 0.78 & 2.69 & 0.10 & 4.99 & 8.56 & 49.48 \\
\hline Site 7 & I & $90 \mathrm{~cm}$ & 0.99 & 2.45 & 0.18 & 6.78 & 10.40 & 12.45 \\
\hline
\end{tabular}

The presence of oxalate, according to the scientific literature, could be related to restoration works carried out in the past or to the presence of biological activity (Griffin et al. 1991; El-Metwally and Ramadan 2004; Barone et al. 2008; Belfiore et al. 2010, 2013; Gulotta et al. 2013).

The origin of silicates, instead, could be ascribable to two sources: primary, namely from the substrate where they are naturally present; or secondary, from the deposit of soil dust. In the first case, in fact, during the sulphation process, minerals such as quartz, present in the substrate, do not undergo the attack of sulphuric acid and can be incorporated into the crust during the gypsum precipitation process.

\section{Carbonaceous fraction}

The carbonaceous material (total carbon, TC) is classified into elemental carbon (EC) (better known as black carbon (BC)) and organic carbon (OC). The analysis of these components is of great interest for the study of black crusts (La Russa et al. 2017). The EC fraction has a graphitic structure and represents a primary pollutant, directly emitted during the combustion processes. The OC fraction is composed of different classes of compounds (e.g. hydrocarbons, oxygenated) and may have a primary or secondary origin. The carbonaceous components are involved in some heterogeneous chemical reactions that

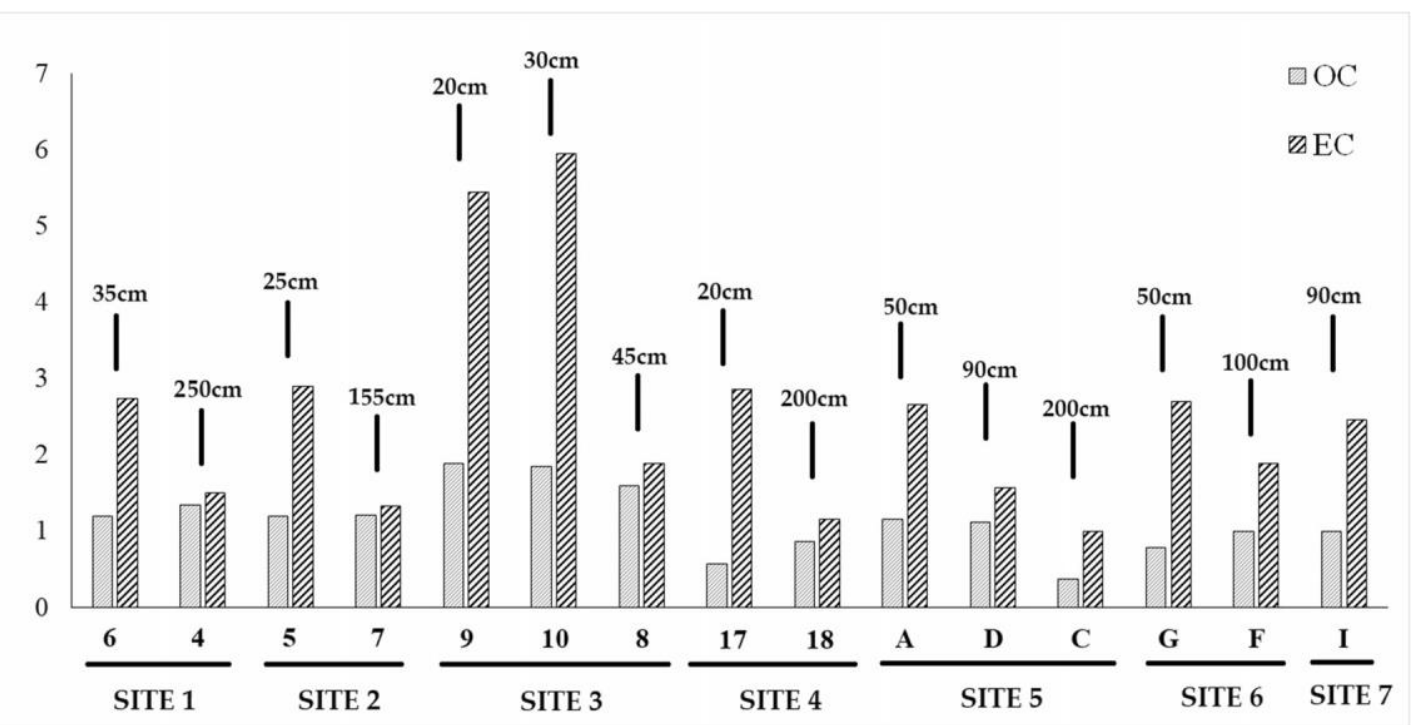

Fig. 6 OC and EC values (wt.\%) obtained in the different specimens in relation to the sampling height 


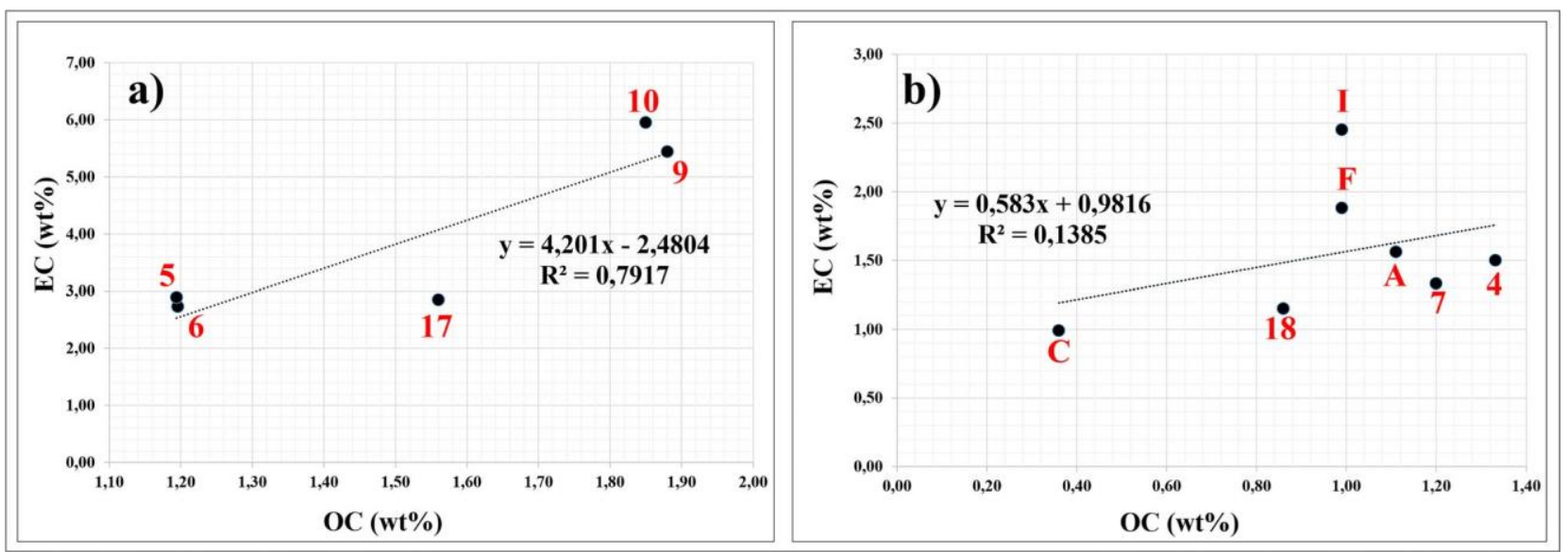

Fig. 7 Scatter plots of OC and EC concentrations for the samples. a Samples 5,6,9,10 and 17 taken at low heights. b Samples 4, 7, 18, A, C, F and I taken at high heights

occur in the atmosphere, acting with $\mathrm{SO}_{2}, \mathrm{NO}_{2}, \mathrm{O}_{3}$ and other gaseous components (Avino et al. 2000, 2002; Atkinson and Arey 2003; Donahue et al. 2005); they are also responsible for some degradation processes, accelerating the corrosion phenomena of metals or the formation of black crusts (Barca et al. 2014; Comite et al. 2012, 2019, 2020; La Russa et al. 2013b, 2017, 2018; Ruffolo et al. 2015). In addition to EC and OC, the carbonaceous fraction (TC) of the black crusts also includes the CC (carbonatic carbon), coming from the stone substrate and oxalates $(\mathrm{Ox})$, whose origin may depend on different factors as previously described in the FT-IR/ATR study.

Table 4 shows the carbon fraction detected in the analysed samples and the various ratios of OC/EC, EC/TC and OC/TC.

The samples show a variable content in TC (Table 4) ranging from a maximum of about 15 (for sample 9) to a minimum of about 5 (for sample 18).

Different OX (oxalate) and CC (carbonatic carbon) values were observed for the different crust samples analysed, as, coherently, already recognised in the IR analysis (La Russa et al. 2017, 2018) (Table 3).

High CC values were detected for most of the samples (i.e. 8, 9, 10, 17, F and I), suggesting a possible greater susceptibility to substrate degradation over time (Comite and Fermo 2018; La Russa et al. 2017, 2018). Overall, the data show that all the samples have higher EC contents than OC. Specifically, (a) the highest EC values (wt.\%) were detected in samples 8 and 9 (approximately 6); (b) intermediate values in samples 5, 6, 17, D and G (approximately 3); and (c) the slightly lower values in samples 4 , 7, 18, A, C, F and I (between about 2.5 and 1).

As is well known, the EC (or black carbon) represents the factor that determines the colouring of the black crust (Ghedini et al. 2006; Tidblad et al. 2012; Fermo et al. 2015); therefore, a great amount within the degradation layer can affect greater damage on the monument's surface. Indeed, the dark colouring produces a different susceptibility to absorb solar radiation, causing a greater dilation of the altered stone material compared with that of the unaltered one. Besides, the difference linear expansion, due to the linear expansion coefficient of calcium sulphate (i.e. the main component of the crust) which is greater than that revealed in the carbonatic stone substrate, could lead to greater damage in the calcareous materials characterising the studied monuments.

Figure 6 shows the values of OC (wt.\%) and EC (wt.\%) obtained in relation to the site and the sampling height. The histograms suggest how the values of the OC and EC components decrease as the sampling height increases, highlighting a good correlation between them.

Data indicate that the lower surfaces of the studied monuments are more affected by the deposition processes compared with the higher ones; consequently, they may be affected by greater exposure to the damage processes induced by pollution. A larger amount of the two carbon components $\mathrm{OC}$ and $\mathrm{EC}$ was observed in the samples 9 and 10 taken at about $20-30 \mathrm{~cm}$ from the walking surface; lower accumulations were instead observed mainly in samples taken between 200 and $250 \mathrm{~cm}$ in height. Moreover, it is also evident that there is no correlation between the values obtained at the same height in different sites.

Generally, the formation of black crusts is conditioned by various factors, firstly the deposition surfaces, washouts and exposure to polluting sources. The identification of these latter ones, by the means of OC and EC concentrations, is crucial in the study area. In fact, they should provide precious information about the main degradation processes affecting the surfaces examined.

The scatter plots show the OC and EC (Fig. 7a, b) concentrations for each sample taken at the low heights (samples 5, 6, 9, 10 and 17, heights ranging from 20 to $35 \mathrm{~cm}$ ) (Fig. 7a) and high heights (samples 4, 7, 18, A, C, F and I, heights ranging from 90 to $250 \mathrm{~cm}$ ) (Fig. 7b). Strong correlations between OC and $\mathrm{EC}$ have been found for samples coming from low heights 
$\left(R^{2}=0.7917\right)$. This data indicates that the carbonaceous fraction detected on these surfaces originated mainly from common sources and also influenced by similar transport processes (Na et al. 2020). Conversely, the samples taken at higher heights (i.e. samples 4, 7, 18, A, C, F and I, height between 90 and $250 \mathrm{~cm})$ showed relatively poor correlations $\left(R^{2}=\right.$ 0.1385 ) which could indicate that the carbonaceous fraction on the surfaces has different origins ( $\mathrm{Na}$ et al. 2020).

\section{State of conservation and proposals of intervention strategies}

The substrates analysed show within a fair state of conservation, even if the incipient fractures and the observed dissolution phenomena represent probable predisposing factors for the development of further degradation processes. The study conducted affirms that currently, the most harmful decay phenomena affect the superficial portions of the stone substrates. Indeed, it was identified mainly black crusts rich in gypsum, soluble salts (e.g. nitrates, chlorides) and accumulation of other pollutants, as how the determination of carbonaceous fraction suggested. The analyses carried out highlighted how environmental pollution, primarily air pollution, constitutes the main threat to the conservation of monuments in Historic Cairo. Moreover, the data collected underline the need for targeted interventions based on a detailed characterisation of the degradation products. In fact, the choice of the most suitable methods can depend, for example, from the morphology and extension of black crusts above and inside the substrate and, in the case of soluble salts, from their different behaviour.

There are, in fact, two types of salts: slightly soluble and highly soluble salts. Gypsum is the main exponent of the slightly soluble salts (Arnold 1983). They produce more intense damages because they crystallise immediately below the surface causing bulging, detachment and loss of fragments.

Highly soluble salts include chlorides and nitrates (Arnold and Zehnder 1991). They can produce dark patches on the substrate thanks to their capacity to reach very high concentrations of highly hygroscopic salts that remain in solution in humid environments.

Conversely, they produce efflorescence phenomena in dry conditions.

Generally, the damages caused by the highly soluble salts are limited to a superficial decohesion, being necessary too high rates of evaporation for triggering a really harmful salt crystallisation.

Overall, the variability and the complexity of the decay phenomena make it necessary to plan specific interventions, capable of mitigating the action of degradation processes such as the above-mentioned formation of black crusts and crystallisation of soluble salts.

In this regard, it would be preferred to adopt suitable cleaning techniques such as laser cleaning in the case of black crusts or periodic treatments based on cellulose pulp packs or using special clays like sepiolite for the extraction of soluble salts from the substrates.

Moreover, it could be useful to plan the application of protective and consolidant treatments selected on the basis of the nature of the substrate and the type of degradation product, in order to extend the effects of cleaning procedures and preserve a good state of conservation of the built heritage over time.

\section{Conclusion}

Historic Cairo represents one of the most representative examples of Islamic architecture. Unfortunately, the built cultural heritage is affected by different and harmful degradation phenomena closely linked, firstly, to the intense environmental pollution and secondly to the intrinsic features of the stone materials used. Seven monumental sites were selected on the basis of their conservation state and eighteen samples of the stone substrate with relative degradation products, mainly black crusts, were taken and analysed by complementary analytical techniques.

Results indicated that the black crusts are generally well adherent to the limestone substrates and present variable thickness, with no particular correlation with the site of provenance. The analyses suggested how the crusts are mainly composed of gypsum with lower content of calcite and oxalates. These latter ones could be related to past restoration works or to the decay produced by biological activity. The IC analyses underlined the great contribution of salts as degradation agents, namely chlorides, nitrates and nitrites. They are produced mainly by anthropic activities such as industry and vehicular traffic and secondly by natural sources as sea spray.

In addition, the determination of the carbonaceous fraction suggests the high incidence of the pollution in the degradation processes affecting the substrates analysed. Besides, according to the measurements of the organic and elemental carbon of the degraded layers, the lower surfaces of the studied monuments are more affected by the deposition process compared with the higher ones.

Overall, the methodological approach applied in this study allowed to collect crucial data about environmental pollution in Historic Cairo to implement with further sampling campaigns in the next researches. It will allow to trace a base mapping of the conservation state of the built heritage, in the area, defining both the main polluting sources and the development of the relative degradation products to investigate more deeply in future studies.

This will provide essential information to conceive effective conservation strategies and suitable restoration interventions based on appropriate cleaning procedures, consolidating and protective products capable of preserving the built cultural heritage of Historic Cairo over time. 


\section{References}

Abdelmegeed M, Hassan S (2019) Diagnostic investigation of decaying limestone in historical buildings at the Mamluks Cemetery- City of the Dead, Egypt. EJARS 9(2):183-196. https://doi.org/10.21608/ ejars.2019.66989

Aly N, Hamed A, Abd El- Al A. (2020) The impact of hydric swelling on the mechanical behavior of Egyptian Helwan limestone. Period Polytech Civil Eng. https://doi.org/10.3311/PPci.15360

Aly N, Wangler T, Török Á (2018) The effect of stylolites on the deterioration of limestone: possible mechanisms of damage evolution. Environ Earth Sci 77:565

Aly N, Gomez-Heras M, Hameda A, Álvarez de Buergo M, Solimane F (2015) The influence of temperature in a capillary imbibition salt weathering simulation test on Mokkattam limestone Materiales de Construcción. Mater Constr 65:317. https://doi.org/10.3989/mc. 2015.00514

Anoniou J (1999) Historic Cairo. A walk through the Islamic City by Jim Anoniou Publisher. The American University in Cairo Press

Araoz G (2008) Annual report. International Council On Monuments and Sites (ICOMOS), Paris

Arnold B (1983) Determination of mineral salts from monuments. Stud Conserv 29:129-138. https://doi.org/10.1179/sic.1984.29.3.129

Arnold A, Zehnder K (1991) Monitoring wall paintings affected by soluble salts. In: Cather S (ed) The conservation of wall paintings. Getty Conservation Institute, Marina del Rey (California), pp 103-135

Atkinson R, Arey J (2003) Gas-phase tropospheric chemistry of biogenic volatile organic compounds: a review. Atmos Environ 37:197-219. https://doi.org/10.1016/S1352-2310(03)00391-1

Avino P, Brocco D, Cecinato A, Lepore L, Balducci C (2002) Carbonaceous components in atmospheric aerosol: measurement procedures and characterization. Ann Chim 92:333-341

Avino P, Brocco D, Lepore L, Ventrone I (2000) Fundamental aspects of carbonaceous particulate measurements in the study of air pollution in urban area. In: Longhurst JWS et al (eds) Air Polluion VIII. Cambridge University, UK, pp 301-309

Barca D, Comite V, Belfiore CM, Bonazza A, La Russa MF, Ruffolo SA, Crisci G, Pezzino A, Sabbioni C (2014) Impact of air pollution in deterioration of carbonate building materials in Italian urban environments. Appl Geochem 48:122-131. https://doi.org/10.1016/j. apgeochem.2014.07.002

Barone G, La Russa MF, Lo Giudice A, Mazzoleni P, Pezzino A (2008) The Cathedral of S. Giorgio in Ragusa Ibla (Italy): characterization of construction materials and their chromatic alteration. Environ Geol 55:499-504

Belfiore CM, Barca D, Bonazza A, Comite V, La Russa MF, Pezzino A, Sabbioni C (2013) Application of spectrometric analysis to the identification of pollution sources causing cultural heritage damage. Environ Sci Pollut Res 20:8848-8859. https://doi.org/10.1007/ s11356-013-1810-y

Belfiore CM, La Russa MF, Pezzino A, Campani E, Casoli A (2010) The baroque monuments of Modica (Eastern Sicily): assessment of causes of chromatic alteration of stone building materials. Appl Phys A Mater Sci Process 100:835-844

Borrelli E (1999) Conservation of architectural heritage, historic structures and materials. Salts, ICCROM, Rome, Italy

Caneva G, Nugari MP, Salvadori O (1991) Biology in the conservation of works of art. ICCROM, Rome, pp 88-91

Comite V, Pozo-Antonio JS, Cardell C, Rivas T, Randazzo L, La Russa MF, Fermo P (2020) Environmental impact assessment on the Monza Cathedral (Italy): a multi-analytical approach. Int J Conserv Sci 11, Special Issue(1):291-304

Comite V, Pozo-Antonio JS, Cardell C, Rivas T, Randazzo L, La Russa MF, Fermo P. Metal distributions within black crusts sampled on the facade of an historical monument: the case study of the Cathedral of
Monza (Milan, Italy). In 2019 IMEKO TC4 International Conference on Metrology for Archaeology and Cultural Heritage, MetroArchaeo, 2019, 73-78

Comite V, Fermo P (2018) The effects of air pollution on cultural heritage: the case study of Santa Maria delle Grazie al Naviglio Grande (Milan). Eur Phys J Plus 133:556. https://doi.org/10.1140/epjp/ i2018-12365-6

Comite V, Barca D, Belfiore CM, Bonazza A, Crisci GM, La Russa MF, Pezzino A, Sabbioni C (2012) Potentialities of spectrometric analysis for the evaluation of pollution impact in deteriorating stone heritage materials. In: Critelli S et al. (eds) Rendiconti online della Società Geologica Italiana. 86 Congresso Nazionale della Società Geologica Italiana. Arcavacata di Rende 21:652-653

Davidson CI, Tang F, Finger S, Etyemezian V, Sherwood SI (2000) Soiling patterns on a tall limestone building: changes over 60 years. Environ Sci Technol 34:560-565

Delgado Rodrigues J, Ferreira Pinto AP (2019) Stone consolidation by biomineralisation. Contribution for a new conceptual and practical approach to consolidate soft decayed limestones. J Cult Herit 39:82-92

Donahue NM, Huff Hartz KE, Chuong B, Presto AA, Stanier CO, Rosenhørn T, Robinson AL, Pandis SN (2005) Critical factors determining the variation in SOA yields from terpene ozonolysis: a combined experimental and computational study. Faraday Discuss 130:295-309.https://doi.org/10.1039/b417369d

Dunham RJ (1962) Classification of carbonate rocks according to depositional textures. Amer Assoc Petrol Geol Mem 1:108-121

El-Metwally AA, Ramadan AB (2004) The role of air pollutants and sewage waste in acceleration of degradation of the Islamic cultural heritage of Cairo. In: Linkov I, Ramadan AB (eds). Comparative Risk Assessment and Environmental Decision Making. Nato Science Series: IV: Earth and Environmental Sciences, 38, Springer, Dordrecht

Fermo P, Turrion GR, Rosa M, Omegna A (2015) A new approach to assess the chemical composition of powder deposits damaging the stone surfaces of historical monuments. Environ Sci Pollut Res 22: 6262-6270. https://doi.org/10.1007/s11356-014-3855-y

Fitzner B, Heinrichs K, La Bouchardiere D (2002) Weathering damage on Pharaonic sandstone monuments in Luxor-Egypt. Build Environ 38:1089-1103. https://doi.org/10.1016/S0360-1323(03)00086-6

Fitzner B, Heinrichs K, La Bouchardiere D (2000) Damage index for stone monuments. In: Galan E, Zezza F (Eds.) Protection and conservation of the cultural heritage of the Mediterranean cities. In: Proceedings of the 5th International Symposium on the Conservation of Monuments in the Mediterranean Basin, Sevilla Spain, 315-326

Folk RL (1959) Practical petrographic classification of limestones. Bull Am Assoc Pet Geol 43:1-38

Gauri KL (1981) The deterioration of ancient stone structures in Egypt. In Prospection et Sauvegarde des Antiquities de l'Egypte: Actes de la table Ronde organisée à l'occasion du Centenaire de l'Institut Français d'Archéologie Orientale. Grimal NC (ed). Bibliotheque d'Etude, Le Caire: institute Francais d'Archeologie Orientale du Caire

Ghedini N, Sabbioni C, Bonazza A, Gobbi G (2006) Chemical-thermal quantitative methodology for carbon speciation in damage layers on building surfaces. Environ Sci Technol 40:939-944

Goudie AS, Viles HA (1995) The nature and pattern of debris liberation by salt weathering: a laboratory study. Earth Surf Process Landf 20: 437-449. https://doi.org/10.1002/esp.3290200505

Griffin PS, Indictor N, Koestler RJ (1991) The biodeterioration of stone: a review of deterioration mechanisms, conservation case histories, and treatment. Internat Biodet 28:187-207

Gulotta D, Bertoldi M, Bortolotto S, Fermo P, Piazzalunga A, Toniolo L (2013) The Angera stone: a challenging conservation issue in the polluted environment of Milan (Italy). Environ Earth Sci 69:1085-1094 
Khallaf MK (2011) Effect of air pollution on archaeological buildings in Cairo. In: Chmielewski A (ed) Monitoring, control and effects of air pollution. IntechOpen, London, pp 179-200

Klemm DD, Klemm R (2001) The building stones of ancient Egypt

- a gift of its geology. J Afr Earth Sci 33:63-642

La Russa MF, Comite V, Aly N, Barca D, Fermo P, Rovella N, Antonelli F, Tesser E, Aquino M, Ruffolo SA (2018) Black crusts on Venetian built heritage, investigation on the impact of pollution sources on their composition. Eur Phys J Plus 133:370. https:// doi.org/10.1140/epjp/i2018-12230-8

La Russa MF, Fermo P, Comite V, Belfiore CM, Barca D, Cerioni A, De Santis M, Barbagallo LF, Ricca M, Ruffolo SA (2017) The Oceanus statue of the Fontana di Trevi (Rome): the analysis of black crust as a tool to investigate the urban air pollution and its impact on the stone degradation. Sci Total Environ 593-594:297-

MF, Ruffolo SA, Belfiore CM, Aloise P, Randazzo L, Rovella N, Pezzino A, Montana G (2013a) Study of the effects of salt crystallization on degradation of limestone rocks. Period. Mineral. 82(1): 113-127. https://doi.org/10.2451/2013PM0007

La Russa MF, Belfiore CM, Comite V, Barca D, Bonazza A, Ruffolo SA, Pezzino A (2013b) Geochemical study of black crusts as a diagnos-tic tool in cultural heritage. Appl Phys A-Mater 113:1151-1162. https://doi.org/10.1007/s00339-013-7912-z

Na L, Xin W, Weizheng H, Siyue S, Wu J (2020) Characteristics and temporal variations of organic and elemental carbon aerosols in PM1 in Changchun, Northeast China. Environ Sci Pollut Res 27: 8653-8661

Monte MD (1991) Stone monument decay and air pollution. In:

Corso I (ed) Weathering and air pollution, Communità delle

Università
Mediterranee, Scuola Universitaria C.U.M. Conservacione dei Monumenti, 101-10

Pires V, Silva ZSG, Simã JAR, Galhano C, Amaral PM (2010)

"Bianco di Asiago" limestone pavement. Degradation and alteration study. Constr Build Mater 24:686694-686694. https://doi.org/10.1016/j. conbuildmat.2009.10.040

Ruffolo SA, Comite V, La Russa MF, Belfiore CM, Barca D, Bonazza A, Crisci GM, Pezzino A, Sabbioni C (2015) Analysis of black crusts from the Seville Cathedral: a challenge to deepen understanding the relationship among microstructure, microchemical features and pol-lution sources. Sci Total Environ 502:157-166

S, Screpanti A, Grøntoft T, Yates T, de la Fuente D, Roots O, Lombardo T, Simon S, Faller M, Kwiatkowski L, Kobus J, Varotsos C, Tzanis C, Krage L, Schreiner M, Melcher M, Grancharov I, Karmanova N (2012) Effects of air pollution on ma-terials and cultural heritage: ICP materials celebrates 25 years of research. Int J Corros 2012:1-16

Vahur S, Teearu A, Peets P, Joosu L, Leito I (2016) ATR-FT-IR spectral collection of conservation materials in the extended region of 4000- 80 cm-1. Anal Bioanal Chem 408:3373-3379. https:// doi.org/10.1007/s00216-016-9411-5

Williams C (2004) Islamic monuments in Cairo: the practical guide. American University in Cairo Press 